\title{
Time-dynamic effects on the global temperature when harvesting logging residues for bioenergy
}

\author{
Torun Hammar ${ }^{1}$, Carina A. Ortiz ${ }^{2}$, Johan Stendahl ${ }^{2}$, Serina Ahlgren ${ }^{1} \&$ Per-Anders Hansson ${ }^{1}$ \\ ${ }^{1}$ Department of Energy and Technology, Swedish University of Agricultural Sciences (SLU), Uppsala, SE-750 \\ 07, Sweden \\ ${ }^{2}$ Department of Soil and Environment, Swedish University of Agricultural Sciences (SLU), Uppsala, SE-750 07, \\ Sweden
}

Correspondence: Torun Hammar, phone: +46 (0)18 6718 30, fax: +46 (0)18 6731 56, e-mail: torun.hammar@slu.se

Primary research

\begin{abstract}
The climate mitigation potential of using logging residues (tree tops and branches) for bioenergy has been debated. In this study, a time-dependent life cycle assessment (LCA) was performed using a single-stand perspective. Three forest stands located in different Swedish climate zones were studied in order to assess the global temperature change when using logging residues for producing district heating. These systems were compared with two fossil reference systems in which the logging residues were assumed to remain in the forest to decompose over time, while coal or natural gas was used for energy. The results showed that replacing coal with logging residues gave a direct climate benefit from a single-stand perspective, while replacing natural gas gave a delayed climate benefit of around 8-12 years depending on climate zone. A sensitivity analysis showed that the time was strongly dependent on the assumptions for extraction and combustion of natural gas. The LCA showed that from a single-stand perspective, harvesting logging residues for bioenergy in the south of Sweden would give the highest temperature change mitigation potential per energy unit. However, the differences between the three climate zones studied per energy unit were relatively small. On a hectare basis, the southern forest stand would generate more biomass compared to the central and northern locations, which thereby could replace more fossil fuel and give larger climate benefits.
\end{abstract}

Keywords: life cycle assessment (LCA), soil organic carbon (SOC), global warming, boreal forest, biogenic carbon, greenhouse gas (GHG) emissions

\section{Introduction}

Climate change is an important issue which needs to be addressed. According to the latest IPCC (Intergovernmental Panel on Climate Change) report, the human-induced emissions of greenhouse gases (GHGs) are the major drivers behind climate change [1]. Reducing GHG emissions is therefore central for mitigating climate change. However, how to reduce these GHG emissions is debated. One proposed strategy is to replace fossil fuels with bioenergy [2]. In the European Union (EU), targets for reducing the release of GHGs have been adopted by the member countries. These goals are referred to as the '20-20-20' targets and include a $20 \%$ decrease of the GHG emissions in the EU, and an increase to $20 \%$ of renewable energy, by year 2020 (compared to year 1990) [3]. Sweden has higher mitigation targets during the same timeframe with a $40 \%$ reduction in GHG emissions and a goal to increase renewable energy to $50 \%$ of the total energy consumption. Sweden has furthermore set the target to generate zero net emissions of GHGs by year 2050 [4].

Sweden already has a relatively high share of bio-based energy (about 23\% including peat) [5]. Forest biomass accounts for a large part, which is commonly used for district heating (DH) [5,6]. Being the fourth largest 
country in the EU, measured by land area, where about 70\% is forest land [7], Sweden has a potential to increase the use of bioenergy from forest biomass. One way is to utilize logging residues (branches and tree tops) from the forest industry, which otherwise would be left in the forest to decompose over time [8]. However, the climate benefits of using woody biomass for energy have been debated [9].

Regardless of whether the forest biomass is extracted or left in the forest, the carbon stored in the biomass will be oxidized into carbon dioxide $\left(\mathrm{CO}_{2}\right)$ by combustion or decomposition. Carbon inputs from the biomass to the soil affect the soil organic carbon content in the forest. The released $\mathrm{CO}_{2}$ will end up in the atmosphere where it will have an effect on the energy balance on Earth. There is however a difference in the timing of $\mathrm{CO}_{2}$ emissions between the two processes. During combustion, $\mathrm{CO}_{2}$ is emitted directly, while decomposition is a slower process that will release $\mathrm{CO}_{2}$ over a longer period of time. This time aspect is especially important to consider when studying conventional forests with longer rotation periods. The decomposition rate also varies between different climate zones, which has been shown to influence the overall climate impact of a bioenergy system [10]. As Sweden covers several climate zones, with warm-temperate zones in the south and cold-temperate zones in the north, these variations are important to consider. The climate variations are reflected in forest productivity, with the longer growing season in the south resulting in higher productivity than in northern Sweden, where the winters are longer and the growing season shorter.

To determine the climate impact of harvesting logging residues, it is important to study the aspect of time [11]. This can be done by using a life cycle assessment (LCA) method which considers GHG emissions released over the entire time frame of the studied system. LCA is commonly used for assessing the climate impact of bioenergy systems [12,7], and is a standardised method (ISO 14040/44) for evaluating the environmental impacts throughout the entire lifespan of a service or product [13-15]. In order to consider the timing of GHG fluxes, a time-dependent LCA method can be used [16-18].

Previous studies of logging residues used for bioenergy have shown climate benefits in relation to fossil fuels [19-21,7,22]. In particular, the changes in soil organic carbon (SOC) and the $\mathrm{CO}_{2}$ fluxes between soil, biomass and atmosphere have been shown to highly influence the result [23,20,24-27]. To model the forest carbon balance, process-based models were used in this study. Climate impact is commonly expressed as radiative forcing (RF), i.e. change in radiative balance of the Earth leading to either a warming or cooling effect on the global temperature. RF can be expressed both as a cumulative climate metric or used as base for calculating global warming potential (GWP). GWP expresses the integrated RF of a gas compared to the integrated RF of another gas (usually $\mathrm{CO}_{2}$ ) during a fixed time frame [28], and thus disregards the time-dependency. To consider the time-dynamic of biogenic carbon, using the cumulative RF for assessing the climate impact is therefore more appropriate. However, using cumulative RF neglects the inertia of the Earth, i.e. delays in climatic processes. Additionally, it can be difficult for e.g. policymakers to interpret RF. In order to clarify the interpretation of an LCA regarding the impact on climate, a time-dependent temperature change metric can be used instead.

Since bioenergy is a central part of both Swedish and international climate change mitigation strategies, it is important to study the effects of utilizing forest biomass as a substitute for fossil fuels, in order to increase the knowledge regarding how future energy systems should be designed. The aim of this study was therefore to study the effects of harvesting logging residues for district heating from a single forest stand, and the timedynamic effects on the global temperature. As reference, no harvest took place and fossil fuel (coal or natural gas) was used for heat production. The study included three different forest sites, located in different boreal climate zones. The changes in carbon stocks, including decomposition of biomass, were modelled with a carbon balance model calibrated for Swedish forest conditions. The time frame was set to the 50 years following final felling.

\section{Materials and method}

A time-dependent LCA was performed following the methodology described by Ericsson et al. [16]. The method captures how the climate impact varies over time by considering the yearly flows of energy and GHGs during the whole time frame of the system studied. The three major GHGs, $\mathrm{CO}_{2}$, methane $\left(\mathrm{CH}_{4}\right)$ and nitrous oxide 
$\left(\mathrm{N}_{2} \mathrm{O}\right)$, were used for calculating the time-dependent temperature change. The climate metric global warming potential (GWP) was also used, to enable comparisons with previous studies. The primary energy use and the energy output were used for assessing the energy efficiency of the forest systems. The results were based on the two functional units MJ district heating (DH) (MJ heat) generated during one forest rotation and per hectare of forest area (ha). A larger forest area is required in northern Sweden than in the south to generate the same amount of bioenergy due to the geographical gradient in forest productivity. As a reference system, the same amount of energy was assumed to be produced from fossil fuels during the same year, while the logging residues were left in the forest to decompose. A carbon balance model was used for assessing the carbon fluxes between the soil, biomass and atmosphere.

\subsection{System boundaries}

This study was limited to three boreal coniferous forest stands representing typical soils and growing conditions in Sweden. The stands were assumed to be located in the regions Jönköping (south), Dalarna (central) and costal part of Västerbotten (north) (Fig. 1). In all three regions, the study was limited to Norway spruce (Picea abies). The harvest of aboveground energy biomass is generally integrated with the harvest of timber in conventional forestry in Sweden [29], and therefore the release of GHG and energy consumed prior to and during final felling were allocated to the production of timber. The management practices and technologies used were assumed to be constant during the whole lifespan of the forest and no improvements were considered. The forest biomass was assumed to be combusted at a DH plant, where there has been a great increase in the use of wood as input fuel during recent years in Sweden [30]. Losses occurring downstream from the DH plant were not included within the system boundaries.

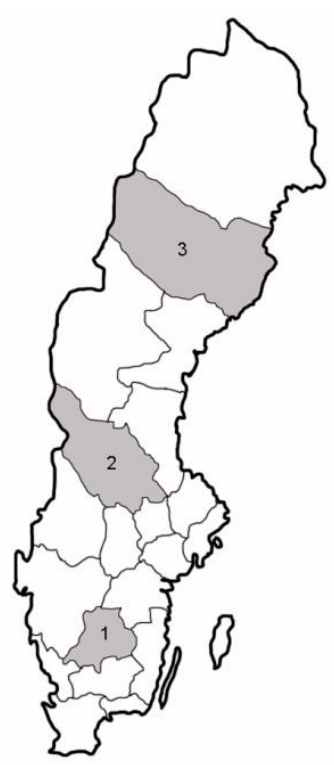

Fig. 1 Map of Sweden showing county borders and the location of the three forest stands studied: (1) South (Jönköping), (2) Central (Dalarna) and (3) North (Västerbotten)

In the inventory analysis, GHG emissions were divided into biogenic $\mathrm{CO}_{2}\left(\right.$ bio $\left.\mathrm{CO}_{2}\right)$ and non-biogenic GHG (non-bio GHG) to distinguish between emissions originating from forest biomass (i.e. the decomposition of litter, soil organic carbon (SOC) changes and biomass combustion) and emissions originating from the use of fossil fuel and as a result of incomplete combustion. The bioenergy system was assumed to replace a fossil reference system, where the potential climate benefits were referred to as the substitution effect. The time frame of the study was set to 50 years for the three forest systems, where harvest and combustion only took place during the first year. 


\subsection{System description}

At final felling, branches and tree tops were assumed to be peeled and cut off the tree by a harvester and then left in small piles in the forest. The logging residues were assumed to be collected and forwarded to the roadside for storage [31]. Thereafter, the residues were assumed to be chipped and transported to a DH plant for combustion (Fig. 2). No harvest was assumed after thinning and the ash was recycled to avoid nutrient deficits.

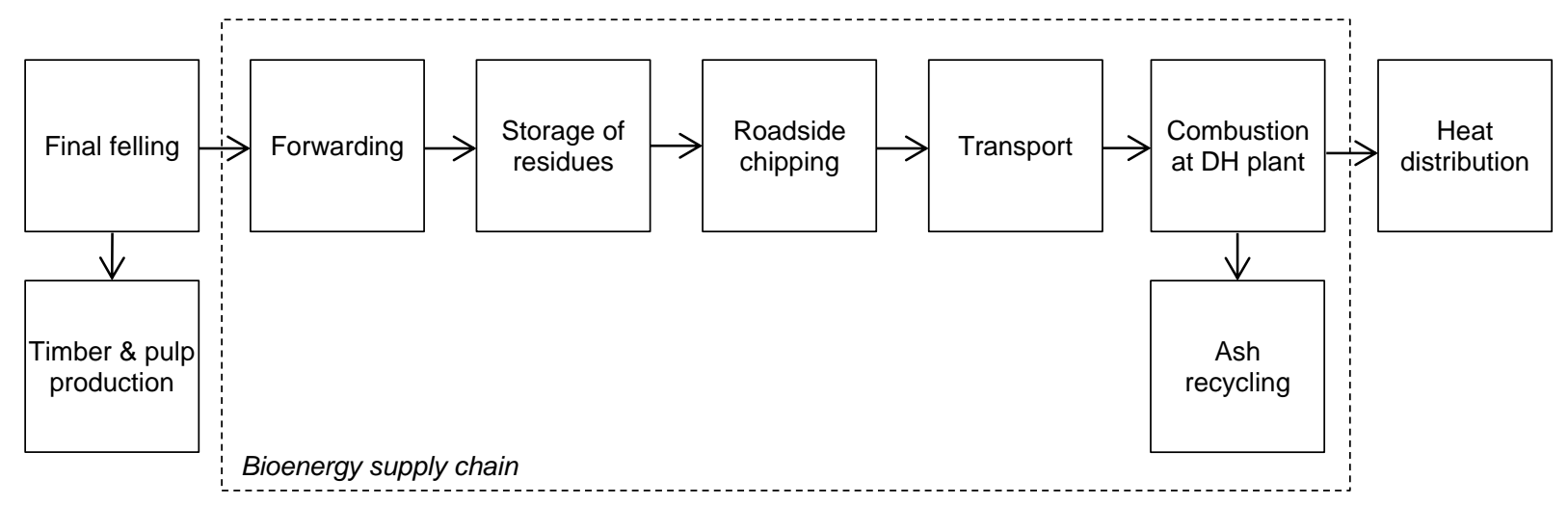

Fig. 2 Processes allocated to the bioenergy supply chain marked by dashed line, where each process includes primary energy use and greenhouse gas fluxes. $\mathrm{DH}=$ district heating

\subsubsection{Forest scenarios}

The three forest stands included in this study represented different vegetation zones and site productivity rates (Table 1). The productivity for each stand was described by a site index based on the maximum tree height achieved at age 100 years (H100) [30]. The decomposition rate varies with climate zone, where the warmer climate in the south is giving rise to faster decomposition compared with northern latitudes.

Table 1 Descriptions of the scenarios (South, Central, North) compared in the analysis

\begin{tabular}{llll}
\hline Scenario & 1 & 2 & 3 \\
\hline Location & South & Central & North \\
Vegetation zone & Jönköping & Dalarna & Västerbotten \\
Latitude & Hemiboreal & Southern boreal & Northern boreal \\
Productivity $(\mathrm{H} 100)^{\mathrm{a}}(\mathrm{m})$ & 32 & $61^{\circ} \mathrm{N}$ & $64^{\circ} \mathrm{N}$ \\
Understory & Herbs, mosses & 24 & 20 \\
Rotation interval $(\mathrm{yr})$ & 70 & Blueberry, mosses & Blueberry, mosses \\
Thinning age(s) $(\mathrm{yr})$ & $25,35,45$ & 90 & 120 \\
\hline
\end{tabular}

${ }^{\mathrm{a}}(\mathrm{H} 100)$ is the maximum tree height at age 100.

\subsubsection{Reference systems}

Each forest system had a corresponding reference system, which was defined as a forest with no harvest of logging residues. Tops and branches were instead assumed to be left in the forest to decompose. Coal or natural gas was instead assumed to be used as alternative feedstock producing the same amount of DH during the same year.

\subsection{Carbon balance}

The living biomass of the forest stands was simulated with the Heureka Forestry Decision Support System (Heureka) [32], which is a series of programmes used for forest planning analysis based on empirical relationships between forest production, forest management, climate and soil productivity conditions. The 
Heureka system can be used for producing projections of forest growing stocks and age, tree species distribution, recreation index, biomass, yield and carbon content in trees and soils at various scales. The system has been used for forest impact analysis on country level, based on current data from the Swedish National Forest Inventory (NFI) [33].

In this study, the stand-wise version of Heureka was used for estimating the forest growth for the three scenarios. By using Heureka, different forest managements can be studied, e.g. the establishment of new stands by planting, sowing or natural regeneration, pre-commercial thinning (cleaning), thinning, fertilisation and final felling (clear-cutting). The system is based on empirical relationships of forest growth obtained from earlier studies and national inventory data. The various components used in Heureka are described in detail in Wikstrom et al. [32].

Assumptions made for the Heureka stand level runs were on the forest productivity, forest management regimes and level of harvest extraction. The soil productivity parameters were used according to Table 1, which were based on average spruce forest soil conditions from the Swedish National Forest Soil Inventory in the three regions north, central and south of Sweden. The soils were mesic (with a ground water depth of 1 to $2 \mathrm{~m}$ ) sandy loamy tills. The depth of the soils were more than $70 \mathrm{~cm}$ with no water movement occurring.

The specific forest management regime for each of the three regions was applied according to conventional spruce management in Sweden and the specific site productivity. The management regimes were retrieved from the thinning schedule and forest management planning tool INGVAR [34], which is based on empirical relationships between management options and forest growth for Swedish conditions. To represent the three regions in this study, average values for site productivity and understory cover were calculated based on the NFI and Swedish Forest Soil Inventory [35].

The levels of harvest residue extraction were based on Peltola et al. [36]. The extraction of the needle residues was $62 \%$ with the restriction that only $70 \%$ is technically feasible to extract leading to an extraction level of $43.4 \%$ for the needles. The branches on the top were assumed to have a level of extraction of $70 \%$, dead braches on the top $90 \%$ and dead branches $75 \%$. For the system analysis the level of technically feasible extraction of $90 \%$ and $50 \%$ was tested which is equivalent to that $58.8 \%$ of the needles was extracted in the $90 \%$ scenario versus $31 \%$ in the $50 \%$ scenario. The extracted living branches from the top were $90 \%$ and $50 \%$, the other dead branches were the same as for the $70 \%$ extraction level.

Changes in SOC stocks in Heureka were simulated with the Q model [37]. It has been applied previously in several Swedish studies on management effects in coniferous forest $[38,39]$. The $\mathrm{Q}$ model simulates decomposition of organic matter and continuously tracks different qualities of organic material that decompose at certain rates depending on the quality of the material at a given time. A refined version of the model that has functions for incorporating decomposition of old organic material and allows for variable climate [40] was used in this study. The parameterisation used in each region was based on the county-wise calibration of the model by Ortiz et al. [41].

\subsection{Energy balance}

To quantify the energy efficiency of the bioenergy system, the energy ratio $\left(E_{r}\right)$ was calculated by dividing the total energy produced $\left(E_{\text {out }}\right)$ at the $\mathrm{DH}$ plant by the total primary energy input $\left(E_{\text {in }}\right)$ :

$E_{r}=\frac{E_{\text {out }}}{E_{\text {in }}}$

This energy efficiency indicator is commonly used for assessing the overall energy output per unit energy input [42].

\subsection{Climate metrics}

Two climate metrics were used in this LCA, GWP 100 and global mean surface temperature change. GWP $_{100}$ measures the relative radiative effect of a given substance compared with another, integrated over 100 years [28]. Multiplying the net emissions of each GHG by its specific $\mathrm{GWP}_{100}$ factor converts the emissions into $\mathrm{CO}_{2}-$ equivalents $\left(\mathrm{CO}_{2}\right.$-eq), where $\mathrm{CO}_{2}$ has a GWP of 1 and $\mathrm{CH}_{4}$ and $\mathrm{N}_{2} \mathrm{O}$ are stronger GHGs, with a respective 28- 
fold and 265-fold stronger GWP in a 100-year time frame [43]. The $\mathrm{CO}_{2}$-eq for all three GHGs were summed to give the total $\mathrm{GWP}_{100}$.

To account for the temporal variations, the time-dependent LCA method described by Ericsson et al. [16] was used. It calculates the global mean surface temperature change at a specific time, referred to as $\Delta T_{s}$. When GHGs are released the atmospheric concentration is altered, which perturbs the energy balance of the Earth. The concentration depends on the atmospheric decay of the specific GHG. The baselines for the atmospheric GHG concentrations were set according to the latest IPCC report $\left(\mathrm{CO}_{2} 390 \mathrm{ppm}, \mathrm{N}_{2} \mathrm{O} 324 \mathrm{ppb}\right.$ and $\left.\mathrm{CH}_{4} 1803 \mathrm{ppb}\right)$, which shows the annual global mean during 2011 [44]. To model the atmospheric decay of $\mathrm{CO}_{2}$, the Bern carbon cycle model was used $[45,43,46]$. For $\mathrm{N}_{2} \mathrm{O}$ and $\mathrm{CH}_{4}$, a simple exponential decay function was used based on the perturbation lifetime of the specific gas. Indirect effects of $\mathrm{CH}_{4}$ were included by adding the fraction of gas oxidised into $\mathrm{CO}_{2}$ during the preceding year [43]. The change in GHG concentration leads to a change in radiative forcing $(\mathrm{RF})$, which describes the perturbation of the energy balance of the Earth in $\mathrm{Wm}^{-2}$ [47]. RF can be either positive or negative, leading to either warming or cooling of the global temperature. A temperature response function, referred to as the absolute global temperature change potential (AGTP), was used for modelling this change [43]. For a detailed explanation of the method, see Ericsson et al. [16].

\subsection{Data collection and assumptions}

\subsubsection{Forest biomass}

For all forest stands, the biomass extraction level was set to $70 \%$ of the available biomass which gave harvest levels of 47.9, 35.3 and 33.5 Mg DM per hectare for the south, central and north of Sweden, respectively. A moisture content of $50 \%$ on a wet weight basis was assumed for the forwarding of the logging residues. The logging residues were thereafter stored for eight months with a dry matter loss of $1 \%$ per month [48]. The moisture content was set to $45 \%$ on a wet weight basis for the chipping, transportation and combustion [49,50].

\subsubsection{Transportation}

The transportation distances were based on average transportation of forest fuel in Sweden (Table 2). The consumption of fuel was set to 0.58 litre diesel per $\mathrm{km}$, which is the average consumption for a vehicle with a full loading rate of $54 \%$ of the distance and a load weight of $34 \mathrm{Mg}$ [51]. The same distance and fuel consumption were assumed for the transportation of forest machines to and from the site. Lubricating oil use for trucks was set to $0.2 \%$ of the diesel consumption [31].

Table 2 Average transportation distance and forest size in the region of the three scenarios studied in Sweden

\begin{tabular}{llll}
\hline Region & Average distance with load $(\mathrm{km})^{\mathrm{a}}$ & ${\text { Average distance round-trip }(\mathrm{km})^{\mathrm{b}}}^{\mathrm{b}}$ & ${\text { Median forest size }(\text { ha })^{\mathrm{c}}}^{\mathrm{c}}$ \\
\hline South & 64.9 & 120.2 & 1.2 \\
Central & 66.2 & 122.6 & 1.6 \\
North & 78.1 & 144.6 & 3.0 \\
\hline${ }^{\mathrm{a}}$ Andersson and Frisk [51]. ${ }^{\mathrm{b}}$ Based on a full loading rate of $54 \%$ of the distance. ${ }^{\mathrm{c}}$ Swedish Forest Agency [30].
\end{tabular}

\subsubsection{Forest operations}

Logging residues were assumed to be forwarded to the roadside by an average forwarder (136 $\mathrm{kW})$ with a fuel consumption of 10.8 litre per effective hour, including delays shorter than 15 minutes [52]. A total forwarding time of 8.4 minutes per $\mathrm{Mg}$ dry matter (DM) was assumed [53]. After storage, logging residues were chipped by a truck-mounted grinder with a fuel consumption of 3.05 litres per $\mathrm{Mg} \mathrm{DM}$, including all operations [54]. A chipping loss of $3.6 \%$ was assumed [31]. The loss of biomass was assumed to be released as $\mathrm{CO}_{2}$ during the first year of the study. Lubricating oil use for forest machines was set to $6 \%$ of the diesel consumption [31].

\subsubsection{Biomass combustion}

The wood chips were assumed to be combusted at a DH plant. A lower heating value (LHV) for dry biomass of 19.2 MJ per kg DM was used [55,31,56], which was adjusted for the specific moisture content by: 


$$
L H V_{M C}=L H V-2.45 \frac{M C}{100-M C}
$$

$\left(\mathrm{MJ} \mathrm{kg}^{-1} \mathrm{DM}\right)$

where $\mathrm{LHV}_{\mathrm{MC}}$ is the theoretic heat gained from wood chips with the specific moisture content (MC) excluding water condensation heat, and 2.45 is the latent heat of water vaporisation at $20^{\circ} \mathrm{C}\left(\mathrm{MJ} \mathrm{kg}^{-1}\right)$ [57]. A part of the latent heat lost by water vaporisation can be recovered by flue-gas condensation, which can give efficiency rates over $100 \%$. To include latent heat recover in this study, the combustion efficiency for wood chips was set to $106 \%$ according to Uppenberg et al. [58]. $\mathrm{CO}_{2}$ emissions due to the combustion of forest biomass were calculated based on a carbon content of $51 \%$ on a dry basis [49,59,50]. Emission factors for $\mathrm{N}_{2} \mathrm{O}$ and $\mathrm{CH}_{4}$ emissions at combustion were set to 0.006 and $0.011 \mathrm{~g} \mathrm{MJ}^{-1}$ fuel, respectively, [50].

\subsubsection{Ash recycling}

To avoid soil depletion when logging resides are extracted from the forest, the ash was assumed to be recycled after combustion. According to the Swedish Forest Agency [60], ash should be recycled if more than $0.5 \mathrm{Mg}$ ash is removed per hectare, and if more than half the needles have been removed from the forest site. The amount of recycled ash varies depending on site index (Table 3). In the present study, ash was assumed to be transported back to the forest site and spread using a converted forwarder [61].

Table 3 Ash recycling data used in the analysis (DM = dry matter)

\begin{tabular}{lll}
\hline & Value & Unit \\
\hline Amount of recycled ash (south, central, north) & $2,3,3^{\mathrm{a}}$ & $\mathrm{Mg} \mathrm{DM} \mathrm{ha}^{-1}$ \\
Forwarder capacity & $6^{\mathrm{b}, \mathrm{c}}$ & $\mathrm{Mg} \mathrm{load}^{-1}$ \\
Loading time & $5^{\mathrm{b}}$ & Minutes \\
Unloading time & $20^{\mathrm{b}}$ & Minutes \\
\hline
\end{tabular}

${ }^{\mathrm{a}}$ Swedish Forest Agency [60]. ${ }^{\mathrm{b}}$ Magnusson and Lindblad [62]. ${ }^{\mathrm{c}}$ Emilsson [61].

\subsubsection{Fossil reference systems}

To assess the climate impact of the two reference systems (coal and natural gas), emission factors for the production, distribution and combustion were used (Table 4). Emission factors for the production and distribution of natural gas are representing an European average, based on both imported gas, mainly from Russia and Algeria, and gas from Western Europe [55].

Table 4 Emission factors used for the production, distribution and combustion of the reference fossil fuels coal and natural gas. In $\mathrm{g} \mathrm{MJ}^{-1}$ fuel

\begin{tabular}{lllll}
\hline & Hard coal & & Natural gas & \\
\hline & $\begin{array}{l}\text { Production and } \\
\text { distribution }^{\mathrm{a}}\end{array}$ & Combustion $^{\mathrm{b}}$ & $\begin{array}{l}\text { Production and } \\
\text { distribution }^{\mathrm{a}}\end{array}$ & Combustion $^{\mathrm{b}}$ \\
\hline $\mathrm{CO}_{2}$ & 4.15 & 93 & 5.53 & 56.8 \\
$\mathrm{~N}_{2} \mathrm{O}$ & 0.0000235 & 0.014 & $2.59 \cdot 10^{-12}$ & 0.0001 \\
$\mathrm{CH}_{4}$ & 0.562 & 0.001 & 0.275 & 0.001 \\
\hline
\end{tabular}

${ }^{\mathrm{a}}$ Gode et al. [55]. ${ }^{\mathrm{b}}$ Paulrud et al. [50].

Natural gas consists mainly of $\mathrm{CH}_{4}$ and gives relatively small $\mathrm{CO}_{2}$ emissions compared with coal, which has higher carbon content. Depending on the proportion of carbon to hydrogen and oxygen, coal combustion generates varying $\mathrm{CO}_{2}$ emissions [63]. Both these fossil fuels release $\mathrm{CH}_{4}$ during the extraction and conversion process due to leakages and incomplete combustion [50,63]. By assuming flue-gas condensation, the combustion efficiency for natural gas was set to $104 \%$, and the efficiency for coal was set to and $89 \%$ [58]. 


\section{Results}

\subsection{Life cycle inventory}

\subsubsection{Greenhouse gases}

The highest carbon content in soil and litter was found in the southern forest stand and the lowest in the northern stand (Fig. 3). The removal of forest biomass reduced the carbon content in all three forest stands. However, the difference in carbon stock between the reference scenarios and biomass extraction scenarios declined over time, and 50 years after final felling the carbon stocks were about the same level, irrespective of whether logging residues were removed or not. This indicates that leaving logging residues at the forest site will release approximately the same amount of $\mathrm{CO}_{2}$ as when the residues are extracted for bioenergy, with the exception that the emissions will be spread out during the whole forest rotation in the reference scenarios, instead of being released as a pulse emission during the first year after harvesting.

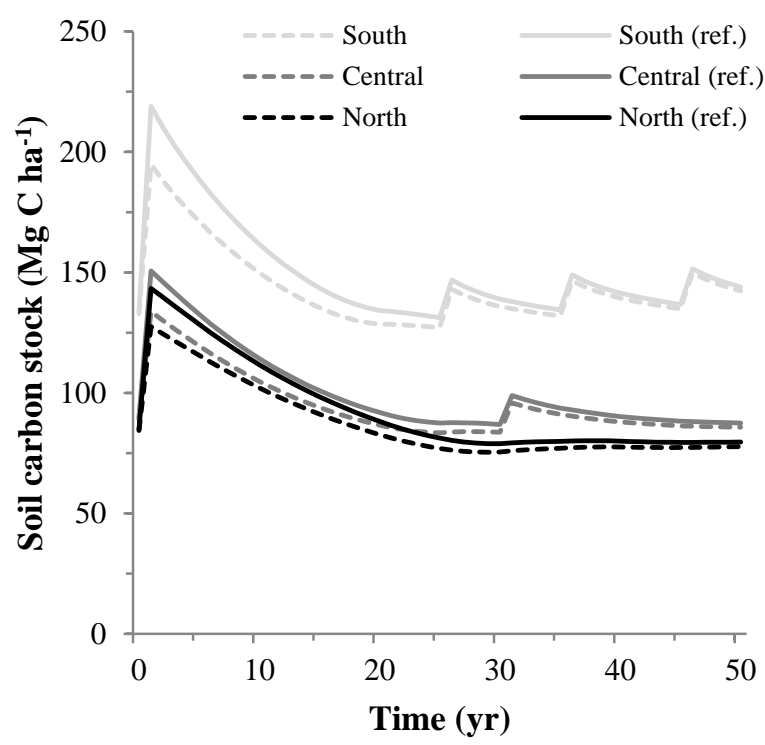

Fig. 3 Carbon content in soil and litter at final felling and during the succeeding 50 years. Dashed lines represents harvest of logging residues and filled lines represent the reference (ref.) scenarios where the residues were left in the forest to decompose. The large peaks during the first year represent the litter input from final felling, and the smaller peaks the litter input from thinnings

The higher biomass extraction level in southern Sweden gave the largest pulse emission of biogenic $\mathrm{CO}_{2}$ per hectare due to biomass combustion (Fig. 4). However, during the following years, the southern forest stand showed the largest decrease in biogenic $\mathrm{CO}_{2}$ emissions compared with the reference scenario where the biomass remained in the forest. This was because litter decomposed faster in the warmer climate zone of southern Sweden. 


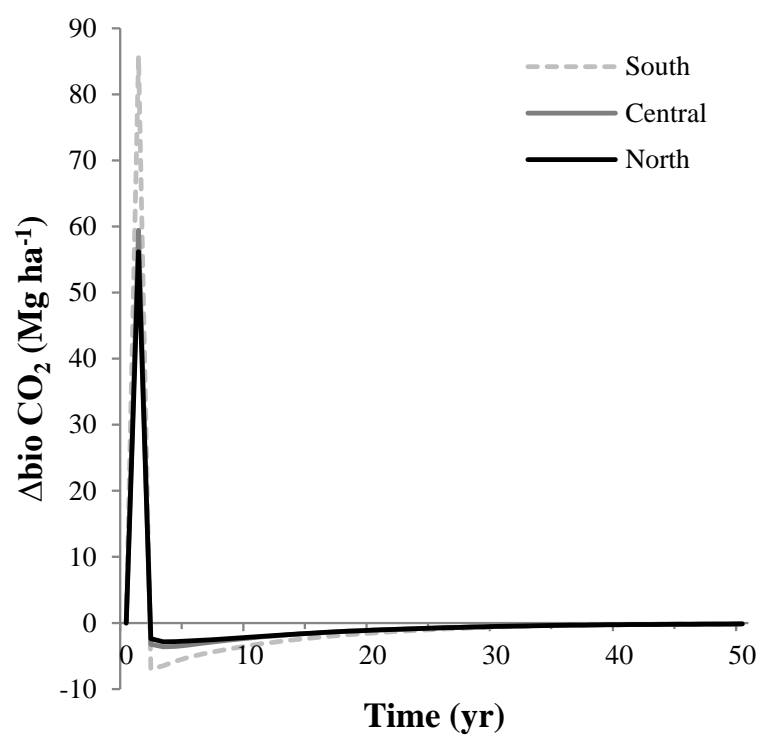

Fig. 4 Yearly differences in biogenic carbon dioxide $\left(\Delta\right.$ bio $\left.\mathrm{CO}_{2}\right)$ release between harvesting logging residues (bioenergy system) and leaving them to decompose in the forest (reference system), during the 50 years following a single harvest. $\Delta$ bio $\mathrm{CO}_{2}$ includes decomposition of logging residues, changes in soil organic carbon and combustion of forest biomass. Positive values indicate that harvesting logging residues for bioenergy emitted more biogenic $\mathrm{CO}_{2}$ than the reference system (due to biomass combustion in year one), and negative values indicate that the bioenergy system emitted less bio $\mathrm{CO}_{2}$ compared with the reference (due to higher decomposition of remaining biomass)

Among the forest stands, the southern forest generated the highest pulse emission of biogenic $\mathrm{CO}_{2}$ due to biomass combustion $\left(85 \mathrm{Mg} \mathrm{ha}^{-1}\right)$, while the central and northern forests generated around the same amount of biogenic $\mathrm{CO}_{2}\left(59-63 \mathrm{Mg} \mathrm{ha}^{-1}\right)$. However, if the logging residues had remained in the forest, the southern forest stand would have released more biogenic $\mathrm{CO}_{2}$ through litter decomposition and SOC changes, while the central and northern stand would have stored the carbon longer. Therefore, the difference between harvesting and not harvesting logging residues was lower for the southern stand during one forest rotation.

The highest fraction of GHG emissions in all three forest scenarios came from biomass combustion. Emissions of non-biogenic GHGs due to the use of fossil fuel during the supply chain differed slightly for the three forest systems due to differences in forest sizes and transportation distances (Table 5).

Table 5 Non-biogenic greenhouse gas emissions from the bioenergy supply chain (forwarding, chipping, transportation, combustion and ash recycling) in the three scenarios, excluding biogenic $\mathrm{CO}_{2}$ fluxes $\left(\mathrm{Mg} \mathrm{ha}^{-1}\right)$

\begin{tabular}{llll}
\hline Scenario & $\mathrm{CO}_{2}$ & $\mathrm{~N}_{2} \mathrm{O}$ & $\mathrm{CH}_{4}$ \\
\hline South & 1.3 & 0.0044 & 0.0086 \\
Central & 0.9 & 0.0033 & 0.0064 \\
North & 0.9 & 0.0031 & 0.0060 \\
\hline
\end{tabular}

\subsubsection{Energy performance}

On a hectare basis, more primary energy was used in the southern forest stand due to higher productivity and thereby higher biomass extraction level (Table 6). The southern forest system also gave the highest energy output per hectare and thereby the highest energy ratio (43, compared with 42 and 41 for the central and northern stand respectively). In the corresponding reference systems, equal amounts of DH were assumed to be produced. 
Table 6 Primary energy use, energy output and energy ratio when forest biomass was harvested from one hectare of land for bioenergy during a single harvest of logging residues from the three forest stands

\begin{tabular}{llll}
\hline Scenario & Energy input $\left(\mathrm{GJ} \mathrm{ha}^{-1}\right)$ & Energy output $(\mathrm{GJ}$ heat ha & -1 \\
\hline South & 18.0 & 770 & Energy ratio \\
Central & 13.6 & 570 & 43 \\
North & 13.2 & 540 & 42 \\
\hline
\end{tabular}

\subsection{Life cycle impact assessment}

\subsubsection{Global warming potential}

The $\mathrm{GWP}_{100}$ for the processes included in the supply chain of logging residues was approximately $3.5-3.6 \mathrm{~g}$ $\mathrm{CO}_{2}$-eq per $\mathrm{MJ}$ heat produced for the three forest stands. Including the net effect of biogenic carbon fluxes 50 years after final feeling gave a total $\mathrm{GWP}_{100}$ of 13-25 $\mathrm{g} \mathrm{CO}_{2}$-eq per $\mathrm{MJ}$ heat, where the southern forest stand gave the lowest warming potential (Fig. 5). The $\mathrm{GWP}_{100}$ for coal and natural gas was about 130 and $70 \mathrm{~g} \mathrm{CO}_{2}$-eq per MJ heat, respectively. If the coal reference systems would be replaced by logging residues, the potential $\mathrm{GWP}_{100}$ savings would be $80-90 \%$ for the three forest stands. The corresponding values for natural gas would be $60-80 \%$, where the southern forest stand would give the highest saving potential.

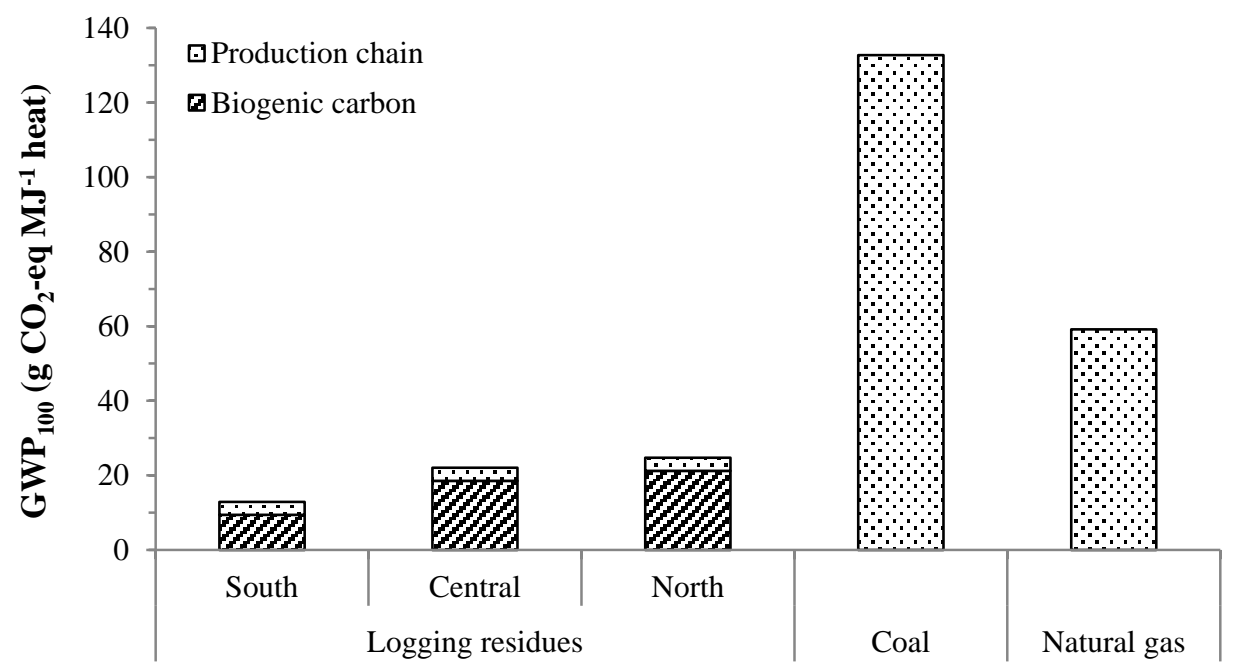

Fig. 5 Global warming potential during a 100 year time frame $\left(\mathrm{GWP}_{100}\right)$ district heating produced from logging residues, coal or natural gas. Biogenic carbon refers to the net emissions 50 years after final felling, i.e. the difference between biomass combustion (harvest) and decomposition (no harvest) in the three regions

\subsubsection{Temperature response}

The climate impact assessment showed that bioenergy from the southern stand gave the lowest warming effect when only considering the biogenic $\mathrm{CO}_{2}$ balance, followed by the central and the northern forest stand (Fig. 6). The temperature response of harvesting logging residues for bioenergy in the three regions showed the highest warming effect after the biomass combustion. After time, as the carbon stored in the biomass would have been released anyway through decomposition, the temperature response declined. 


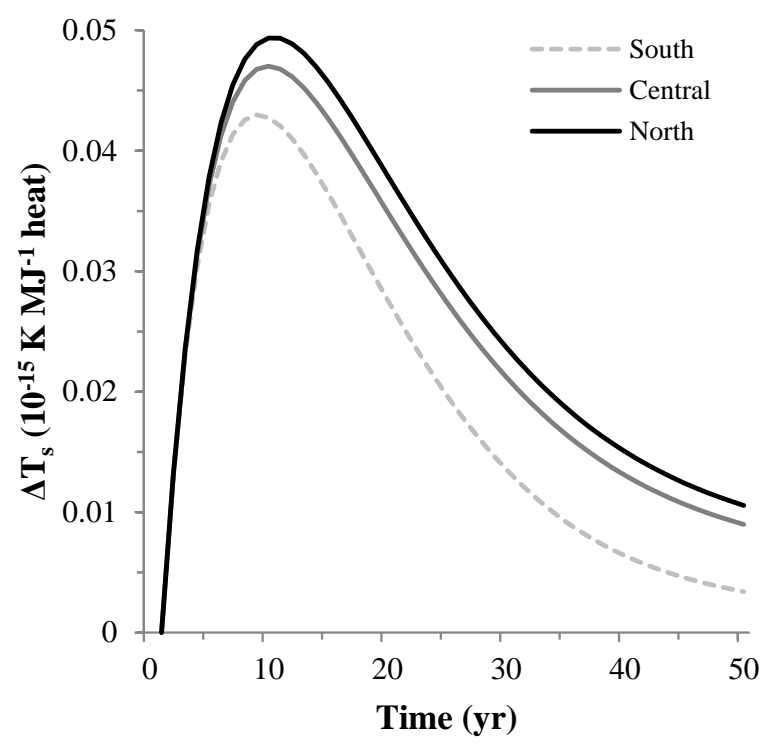

Fig. 6 Net temperature effect $\left(\Delta \mathrm{T}_{\mathrm{s}}\right)$ during the first 50 years following a single harvest due to biomass combustion, litter decomposition and changes in soil organic carbon. The diagram shows the difference between harvesting logging residues for bioenergy and leaving the residues in the forest to decompose. Only changes in biogenic carbon, and no other GHG emissions from the supply chains, are included

If coal was replaced by logging residues for $\mathrm{DH}$ production, there would be an immediate climate mitigation effect, and the largest climate benefit would be gained if logging residues from the southern forest system were used. Unlike the coal reference system, it would take around 8-12 years before replacing natural gas with bioenergy would have a climate mitigating effect, viewed from a single-stand perspective (Fig. 7).

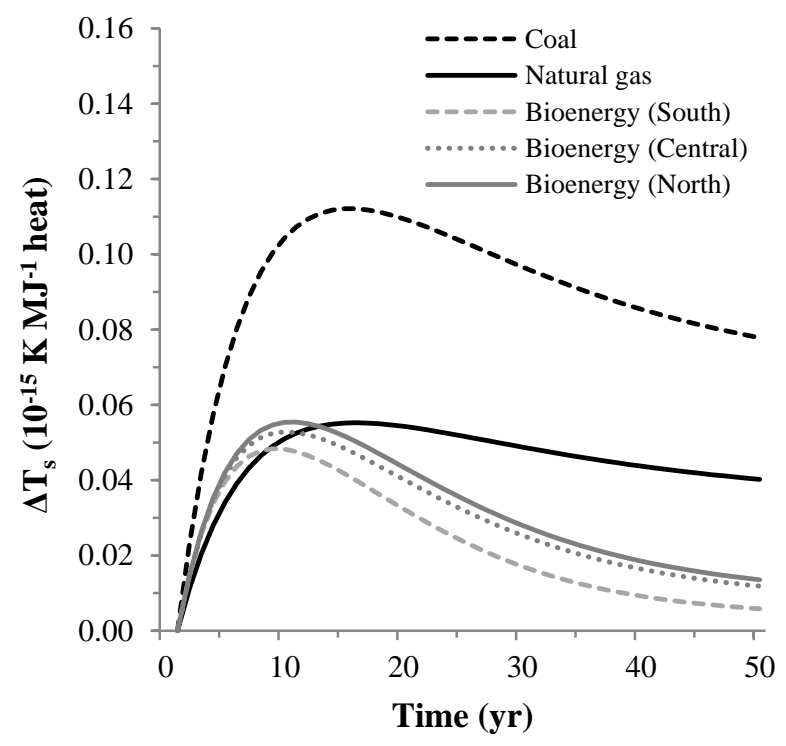

Fig. 7 Net temperature effect $\left(\Delta \mathrm{T}_{\mathrm{s}}\right)$ during the first 50 years following a single harvest for the southern, central and northern forest stands, where the bioenergy curves includes biogenic carbon dioxide emissions from biomass combustion, changes in soil organic carbon and decomposition of forest litter, and non-biogenic greenhouse gas emissions from the supply chain. The two fossil reference systems (coal, natural gas) include non-biogenic greenhouse gases 


\subsection{Sensitivity analysis}

Greenhouse gas emissions from the use of natural gas can vary due to both the composition of the gas, and because of differences in the production and distribution chain. A major source is methane leakage during the distribution chain. To study this uncertainty, a sensitivity analysis was performed where emission factors of natural gas were varied. When lower emissions factors based on natural gas from the North Sea fields were used [64], the climate mitigating potential of replacing natural gas with logging residues was shown to be delayed by about 8 years (Fig. 8). The largest difference between the emission factors was the amount of methane emitted during the production and distribution of the gas.

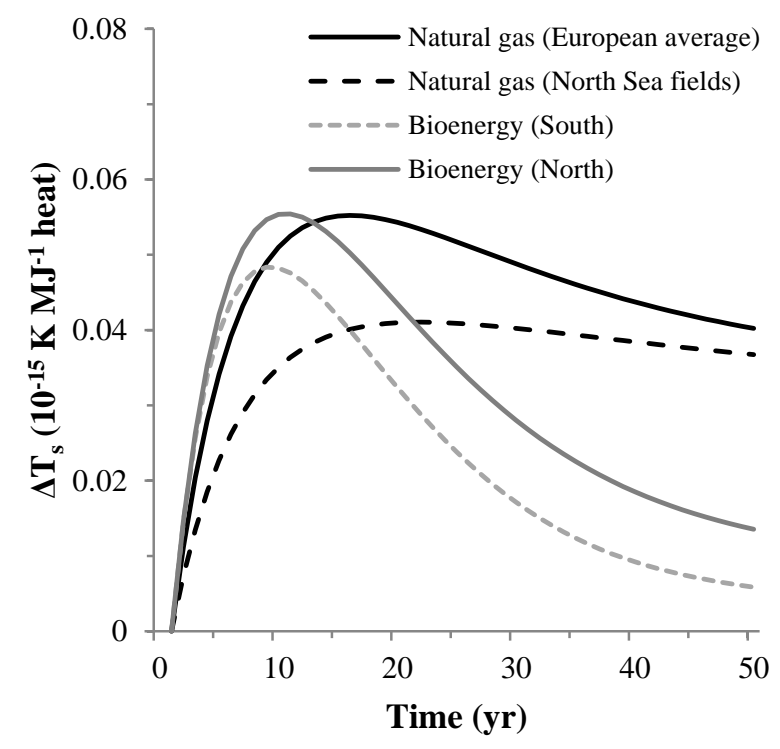

Fig. 8 Sensitivity analysis where alternative emission factors for natural gas were used. The diagram shows the time-dependent temperature effect $\left(\Delta \mathrm{T}_{\mathrm{s}}\right)$ based on data of natural gas from the North Sea fields and based on European average data

The biomass extraction level was also varied in a sensitivity analysis. On a hectare basis, extracting $90 \%$ of the biomass from the southern forest stand gave a higher pulse emission of biogenic $\mathrm{CO}_{2}$ due to biomass combustion, than when the biomass extraction level was decreased to 50\% (Fig. 9). The higher extraction level would lead to a higher climate mitigation potential on a hectare basis, since more fossil energy could be substituted (approximately 560-960 GJ heat ha ${ }^{-1}$ ). However, on an energy basis, the differences in temperature response between the three extraction levels were minimal since the reference scenario and decomposition rate were the same in all three cases. 


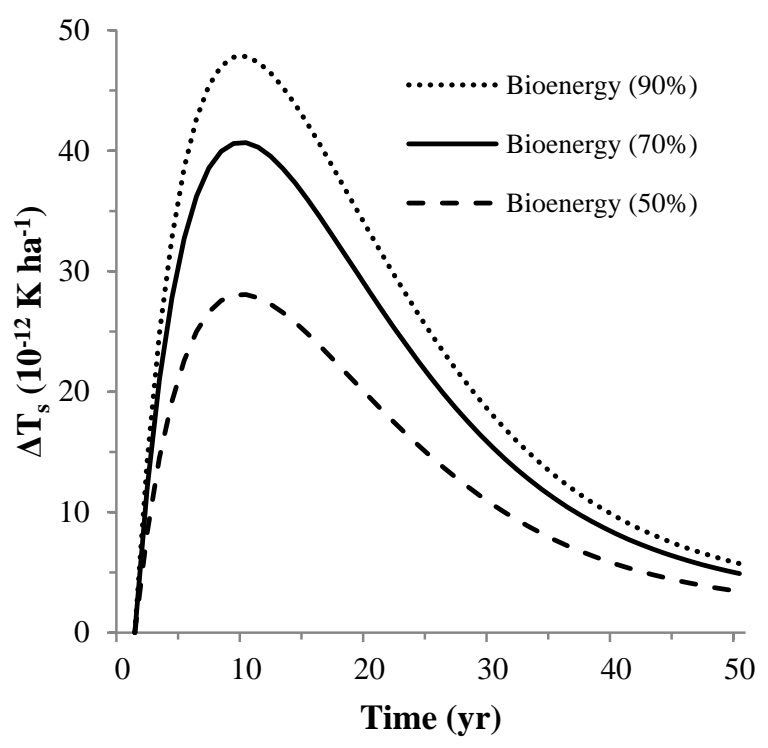

Fig. 9 Sensitivity analysis where the biomass extraction level from the southern forest stand was varied by $\pm 20 \%$. The diagram shows the time-dependent temperature effect $\left(\Delta \mathrm{T}_{\mathrm{s}}\right)$ per hectare due to emissions of biogenic carbon dioxide from biomass combustion, litter decomposition and changes in soil organic carbon

\section{Discussion}

In conventional LCA, bioenergy has commonly been considered as carbon neutral. To enable comparisons with previous studies of logging residues, the biogenic carbon fluxes have therefore been excluded in the following comparison. Producing DH from woody biomass from the three forest stands emitted approximately the same amounts of $\mathrm{CO}_{2}, \mathrm{CH}_{4}$ and $\mathrm{N}_{2} \mathrm{O}$ per unit of fuel, not including emissions from combustion (2, 0.0008 and 0.00007 $\mathrm{kg} \mathrm{MJ}^{-1}$ fuel, respectively). This can be compared with the emission factors presented in Gode et al. [55] (1.9, 0.00014 and $0.000064 \mathrm{~g} \mathrm{MJ}^{-1}$ fuel, respectively). The $\mathrm{GWP}_{100}$ of the three forest systems was approximately 3.7$3.8 \mathrm{~g} \mathrm{CO}_{2}$-eq per MJ fuel, only including non-biogenic $\mathrm{GHG}$ emissions from forwarding, chipping, transportation, ash recycling and combustion. Previous studies have shown GWP in the range of $1.8-11 \mathrm{~g} \mathrm{CO}_{2}$-eq $\mathrm{MJ}^{-1}$ fuel $[20,19,55,10]$. However, comparing results from different LCA studies are often problematic due to differences in system boundaries, functional unit and choice of allocation.

A disadvantage with the climate metric GWP is that it does not consider the timing of the emissions, which makes inclusion of biogenic carbon problematic. In this study, the net effect of biogenic carbon 50 years after final felling was included in the $\mathrm{GWP}_{100}$ (Fig. 5). However, if another timeframe would have been chosen, this value might have been different. Therefore, the choice of timeframe is highly important when including biogenic carbon in GWP. A time-dependent climate metric, as temperature response, is more useful by displaying how the climate impact varies over time, which can help to avoid misinterpretations.

The results showed that due to higher forest productivity in the warmer climate zone of southern Sweden, more biomass could be extracted for bioenergy. This gave higher $\mathrm{CO}_{2}$ pulse emissions per hectare due to the combustion of biomass during year one (Fig. 4). However, if the logging residues remained in the forest, the biomass would decompose faster in the south than in the colder central and northern regions. This means that during the remaining years of the forest rotation, the southern forest would emit more $\mathrm{CO}_{2}$ due to decomposition if the logging residues were not harvested. As a result, the climate mitigation effects per unit of DH produced during one forest rotation from one forest stand would be larger when logging residues are harvested in the south of Sweden, which agrees with the conclusions found in Repo et al. [10]. 
The life cycle impact assessment showed that the average yearly temperature change during the 50 years following the harvest of logging residues was $0.024,0.030$ and $0.03210^{-15} \mathrm{~K} \mathrm{MJ}^{-1}$ heat for the southern, central and northern forest stands, respectively, when logging residues were harvested for bioenergy, not including the substitution effect of replacing fossil fuel. This is comparable to the average temperature change of 0.021-0.028 reported by Zetterberg and Chen [18], which was calculated on a 100-year time frame. The climate impact of harvesting logging residues for bioenergy was shown to vary to a relatively small degree between the three forest stands, indicating that climate zone has a minor impact on the temperature response per unit of heat produced during one forest rotation. However, the rotation length varies between the three regions studied here $(70,90$ or 120 years), which means that the southern forest stand can generate more $\mathrm{DH}$ during a given period than the northern forest stand. If the climate impact were calculated on a hectare basis, the climate mitigation potential would be greater in southern Sweden, since a smaller forest area is needed to produce a given amount of DH than in central or northern Sweden. In other words, it is more land use-efficient to harvest logging residues in the warmer climate zones of Sweden, as also reflected in the higher energy ratio (Table 6). The primary energy use in the present study was in the range $24-26 \mathrm{~kJ}$ per MJ fuel for all forest stands. This is in line with the energy use reported by Lindholm et al. [31] (27 kJ per MJ fuel).

The magnitude of the climate mitigation potential of bioenergy depends on the fossil fuel replaced. Natural gas is delivered to southern Sweden by pipeline from Denmark and the gas supply only reaches a limited part of the country. However, even though natural gas may not be a realistic alternative for northern Sweden today, it is still useful for a general comparison between the fuels. In this study, replacing coal showed an instant climate mitigation effect, whereas natural gas gave a delayed effect of 8-12 years. Previous studies with similar system boundaries have shown delayed climate mitigation effects in the range of 4-50 years when replacing natural gas [7]. The delayed climate mitigation effect when replacing natural gas with logging residues was shown to be highly dependent on used emission factors (Fig. 8).

The climate mitigation potential of varying the biomass extraction level was assessed in a sensitivity analysis. When the harvesting level was altered by $\pm 20 \%$ it was found that the climate mitigation potential was enhanced with higher biomass removal on a hectare basis, since the bioenergy replaced more fossil fuel. However, increasing the harvesting level may affect future forest productivity as a consequence of soil nutrient removal. Moreover, it may have a negative impact on biodiversity.

This LCA was performed from a single-stand perspective, where the forest biomass was assumed to be harvested during one year. This perspective was used to study how the climate gradient in Sweden influences the temperature change potential when logging residues were harvested. The assessment showed that the largest difference between the three studied regions was between the southern climate zone (hemiboreal) and the two northern zones (southern and northern boreal). An alternative perspective would be to use a landscape-view, which assumes that a part of the managed forest area is harvested each year to provide a continuous flow of biomass $[65,66]$. Studies using a landscape-level approach have shown that continuous removal of forest biomass could result in a permanent decrease in forest carbon stocks [12]. This study show that the climate benefits of substituting fossil energy outweighs the decreased carbon stock, from a stand-view perspective.

\section{Conclusions}

The main conclusions from the present study were that: (1) harvesting logging residues for energy generates high biogenic $\mathrm{CO}_{2}$ emissions due to biomass combustion, although this $\mathrm{CO}_{2}$ would otherwise be released over a longer time period through decomposition; (2) even though the harvest of logging residues gave slightly decreased soil carbon content after 50 years from harvest, the logging residue system gave lower warming potential compared to the fossil fuel alternatives; and (3) that replacing coal with logging residues would give an immediate climate benefit from a forest stand perspective, while replacing natural gas would give a delayed climate benefit of around 8-12 years depending on climate zone. The climate mitigating potential was shown to be highly dependent of used emission factors, and the delayed climate benefits of replacing natural gas with logging residues was about 8 years longer when alternative emission factors were used in a sensitivity analysis. 
This time-dependent LCA also showed that from a single-stand perspective, harvesting logging residues for bioenergy in southern Sweden would give slightly higher climate benefits per unit of DH produced during one forest rotation than harvesting logging residues in central and northern Sweden. On a hectare basis, the climate benefits of the southern forest stand would be larger, since it generates more biomass per forest stand, which could replace more fossil fuel and thereby give a larger avoided rise in global temperature compared with fossil energy.

\section{Acknowledgements}

This project was funded by the Swedish Energy Agency (project number 36089-1).

\section{Compliance with Ethical Standards}

The authors declare that they have no conflict of interest.

\section{References}

1. IPCC (2013) Summary for Policymakers. In: Climate Change 2013: The Physical Science Basis. Contribution of Working Group I to the Fifth Assessment Report of the Intergovernmental Panel on Climate Change. Cambridge, United Kingdom and New York, NY, USA.

2. Chum H, Faaij A, Moreira J, Berndes G, Dhamija P, Dong H, Gabrielle B, Goss Eng A, Lucht W, Mapako M, Masera Cerutti O, McIntyre T, Minowa T \& Pingoud K (2011) Bioenergy. In IPCC Special Report on Renewable Energy Sources and Climate Change Mitigation. Cambridge, United Kingdom and New York, NY, USA.

3. European Commission (2013) The EU climate and energy package. European Commission.

4. Swedish EPA (2014) Sweden's climate policy www.swedishepa.se/en/Environmental-objectives-andcooperation/Swedish-environmental-work/Work-areas/Climate/Climate-policy/. Accessed 2014-11-10.

5. Swedish Energy Agency (2014) Energy in Sweden 2013. ET 2013:29.

6. Björheden R (2006) Drivers behind the development of forest energy in Sweden. Biomass and Bioenergy 30 (4):289-295. doi:doi:10.1016/j.biombioe.2005.07.005.

7. Matthews R, Sokka L, Soimakallio S, Mortimer N, Rix J, Schelhaas M-J, Jenkins T, Hogan G, Mackie E, Morris A \& Randle T (2014) Review of literature on biogenic carbon and lifecycle assessment of forest bioenergy. Final Task 1 report, DG ENER project, 'Carbon impacts of biomass consumed in the EU'. Forest Research: Farnham.

8. de Jong J, Akselsson C, Berglund H, Egnell G, Gerhardt K, Lönnberg L, Olsson B \& von Stedingk H (2014) Consequences of an increased extraction of forest biofuel in Sweden - a synthesis from the biofuel research programme 20072011. Summary of synthesis report. IEA Bioenergy Task 43. Report 2014:01.

9. Zanchi G, Pena N \& Bird N (2012) Is woody bioenergy carbon neutral? A comparative assessment of emissions from consumption of woody bioenergy and fossil fuel. GCB Bioenergy 4 (6):761-772. doi:10.1111/j.1757-1707.2011.01149.x.

10. Repo A, Känkänen R, Tuovinen J-P, Antikainen R, Tuomi M, Vanhala P \& Liski J (2012) Forest bioenergy climate impact can be improved by allocating forest residue removal. GCB Bioenergy 4 (2):202-212. doi:10.1111/j.17571707.2011.01124.x.

11. Repo A, Tuomi M \& Liski J (2011) Indirect carbon dioxide emissions from producing bioenergy from forest harvest residues. GCB Bioenergy 3 (2):107-115. doi:10.1111/j.1757-1707.2010.01065.x.

12. Agostini A, Giuntoli J \& Boulamanti A (2013) Carbon accounting of forest bioenergy. Conclusions and recommendations from a critical literature review. Report EUR 25354 EN. Publications Office of the European Union, Luxembourg.

13. Cherubini F (2010) GHG balances of bioenergy systems - Overview of key steps in the production chain and methodological concerns. Renewable Energy 35 (7):1565-1573. doi:10.1016/j.renene.2009.11.035.

14. ISO (2006) ISO 14040:2006. Environmental management. Life cycle assessment - Principle and Framework. Geneva.

15. ISO (2006) ISO 14044:2006. Environmental management - Life cycle assessment - Requirements and guidelines. Geneva.

16. Ericsson N, Porsö C, Ahlgren S, Nordberg Å, Sundberg C \& Hansson P-A (2013) Time-dependent climate impact of a bioenergy system - methodology development and application to Swedish conditions. GCB Bioenergy 5 (5):580-590. doi:10.1111/gcbb.12031.

17. Levasseur A, Lesage P, Margni M, Deschênes L \& Samson R (2010) Considering Time in LCA: Dynamic LCA and Its Application to Global Warming Impact Assessments. Environmental Science \& Technology 44 (8):3169-3174. doi:10.1021/es9030003.

18. Zetterberg L \& Chen D (2014) The time aspect of bioenergy - climate impacts of solid biofuels due to carbon dynamics. GCB Bioenergy (in press). doi:10.1111/gcbb.12174.

19. Jäppinen E, Korpinen O-J, Laitila J \& Ranta T (2014) Greenhouse gas emissions of forest bioenergy supply and utilization in Finland. Renewable and Sustainable Energy Reviews 29 (0):369-382. doi:10.1016/j.rser.2013.08.101. 
20. Lindholm E-L, Stendahl J, Berg S \& Hansson P-A (2011) Greenhouse gas balance of harvesting stumps and logging residues for energy in Sweden. Scandinavian Journal of Forest Research 26 (6):586-594. doi: $10.1080 / 02827581.2011 .615337$.

21. Wihersaari M (2005) Greenhouse gas emissions from final harvest fuel chip production in Finland. Biomass and Bioenergy 28 (5):435-443. doi:10.1016/j.biombioe.2004.11.007.

22. Guest G, Cherubini F \& Strømman A (2013) Climate impact potential of utilizing forest residues for bioenergy in Norway. Mitigation and Adaptation Strategies for Global Change 18 (8):1089-1108. doi:10.1007/s11027-012-9409-z.

23. Buchholz T, Friedland AJ, Hornig CE, Keeton WS, Zanchi G \& Nunery J (2014) Mineral soil carbon fluxes in forests and implications for carbon balance assessments. GCB Bioenergy 6 (4):305-311. doi:10.1111/gcbb.12044.

24. Helin T, Sokka L, Soimakallio S, Pingoud K \& Pajula T (2013) Approaches for inclusion of forest carbon cycle in life cycle assessment - a review. GCB Bioenergy 5 (5):475-486. doi:10.1111/gcbb.12016.

25. Eriksson E, Gillespie AR, Gustavsson L, Langvall O, Olsson M, Sathre R \& Stendahl J (2007) Integrated carbon analysis of forest management practices and wood substitution. Canadian Journal of Forest Research 37 (3):671-681. doi:10.1139/X06-257.

26. Repo A, Tuovinen J-P \& Liski J (2014) Can we produce carbon and climate neutral forest bioenergy? GCB Bioenergy (in press). doi:10.1111/gcbb.12134.

27. Hammar T, Ericsson N, Sundberg C \& Hansson P-A (2014) Climate Impact of Willow Grown for Bioenergy in Sweden. BioEnergy Research 7 (4):1529-1540. doi:10.1007/s12155-014-9490-0.

28. Ramaswamy V, Boucher O, Haigh J, Hauglustaine D, Haywood J, Myhre G, Nakajima T, Shi GY \& Solomon S (2001) Radiative Forcing of Climate Change. In: Houghton JT, Ding Y, Griggs DJ et al. (eds) Climate Change 2001: The Scientific Basis. Contribution of Working Group I to the Third Assessment Report of the Intergovernmental Panel on Climate Change. Cambridge University Press, Cambridge, United Kingdom and New York, NY, USA, p 881.

29. Routa J, Kellomäki S, Kilpeläinen A, Peltola H \& Strandman H (2011) Effects of forest management on the carbon dioxide emissions of wood energy in integrated production of timber and energy biomass. GCB Bioenergy 3 (6):483-497. doi:10.1111/j.1757-1707.2011.01106.x.

30. Swedish Forest Agency (2013) Swedish Statistical Yearbook of Forestry. Swedish Forest Agency, Jönköping, Sweden.

31. Lindholm EL, Berg S \& Hansson PA (2010) Energy efficiency and the environmental impact of harvesting stumps and logging residues. European Journal of Forest Research 129 (6):1223-1235. doi:10.1007/s10342-010-0412-1.

32. Wikstrom P, Edenius L, Elfving B, Eriksson LO, Lamas T, Sonesson J, Ohman K, Wallerman J, Waller C \& Klinteback F (2011) The Heureka forestry decision support system: an overview. Mathematical and Computational Forestry and Natural Resources Sciences 3 (2):87-94.

33. SLU (2014) Swedish National Forest Inventory. Swedish University of Agricultural Science. www.slu.se/en/collaborative-centres-and-projects/swedish-national-forest-inventory/publications/. Accessed 2014-06-02. 2014

34. Jacobson SP, F., Sikström, S., Nyström, K. \& Övergaard, B. (2008) INGVAR - thinning schedules and forest management planning tool. (In Swedish with English summary). 10 2008. Uppsala, Sweden.

35. SLU (2014) Swedish Forest Soil Inventory. Swedish University of Agricultural Science. www.slu.se/en/collaborativecentres-and-projects/swedish-forest-soil-inventory/. Accessed 2014-06-02. 2014

36. Peltola S, Kilpeläinen H \& Asikainen A (2011) Recovery rates of logging residue harvesting in Norway spruce (Picea abies (L.) Karsten) dominated stands. Biomass and Bioenergy 35 (4):1545-1551. doi:http://dx.doi.org/10.1016/j.biombioe.2010.12.032

37. Rolff C \& Agren GI (1999) Predicting effects of different harvesting intensities with a model of nitrogen limited forest growth. Ecological Modelling 118 (2-3):193-211. doi:10.1016/S0304-3800(99)00043-5.

38. Ågren GI \& Hyvönen R (2003) Changes in carbon stores in Swedish forest soils due to increased biomass harvest and increased temperatures analyzed with a semi-empirical model. Forest Ecology and Management 174 (1-3):25-37.

39. Ågren GI, Hyvönen R \& Nilsson T (2007) Are Swedish forest soils sinks or sources for CO2 - model analyses based on forest inventory data. Biogeochemistry 82 (3):217-227.

40. Ortiz CA, Liski J, Gardenas AI, Lehtonen A, Lundblad M, Stendahl J, Agren GI \& Karltun E (2013) Soil organic carbon stock changes in Swedish forest soils A comparison of uncertainties and their sources through a national inventory and two simulation models. Ecological Modelling 251:221-231. doi:10.1016/j.ecolmodel.2012.12.017.

41. Ortiz C, Karltun E, Stendahl J, Gärdenäs AI \& Ågren GI (2011) Modelling soil carbon development in Swedish coniferous forest soils-An uncertainty analysis of parameters and model estimates using the GLUE method. Ecological Modelling 222 (17):3020-3032. doi:10.1016/j.ecolmodel.2011.05.034.

42. Djomo SN, Kasmioui OE \& Ceulemans R (2011) Energy and greenhouse gas balance of bioenergy production from poplar and willow: a review. GCB Bioenergy 3 (3):181-197. doi:10.1111/j.1757-1707.2010.01073.x.

43. Myhre G, Shindell D, Bréon F-M, Collins W, Fuglestvedt J, Huang J, Koch D, Lamarque J-F, Lee D, Mendoza B, Nakajima T, Robock A, Stephens G, Takemura T \& Zhang H (2013) Anthropogenic and Natural Radiative Forcing Supplementary Material. In: Climate Change 2013: The Physical Science Basis. Contribution of Working Group I to the Fifth Assessment Report of the Intergovernmental Panel on Climate Change. Cambridge, United Kingdom and New York, NY, USA.

44. Hartmann DL, A.M.G. Klein Tank, M. Rusticucci, L.V. Alexander, S. Brönnimann, Y. Charabi, F.J. Dentener, E.J. Dlugokencky, D.R. Easterling, A. Kaplan, B.J. Soden, P.W. Thorne, M. Wild and P.M. Zhai (2013) Observations: 
Atmosphere and Surface. In: Climate Change 2013: The Physical Science Basis. Contribution of Working Group I to the Fifth Assessment Report of the Intergovernmental Panel on Climate Change. Cambridge, United Kingdom and New York, NY, USA.

45. Joos F, Prentice IC, Sitch S, Meyer R, Hooss G, Plattner G-K, Gerber S \& Hasselmann K (2001) Global warming feedbacks on terrestrial carbon uptake under the Intergovernmental Panel on Climate Change (IPCC) Emission Scenarios. Global Biogeochemical Cycles 15 (4):891-907. doi:10.1029/2000GB001375.

46. Joos F, Roth R, Fuglestvedt JS, Peters GP, Enting IG, von Bloh W, Brovkin V, Burke EJ, Eby M, Edwards NR, Friedrich T, Frölicher TL, Halloran PR, Holden PB, Jones C, Kleinen T, Mackenzie FT, Matsumoto K, Meinshausen M, Plattner GK, Reisinger A, Segschneider J, Shaffer G, Steinacher M, Strassmann K, Tanaka K, Timmermann A \& Weaver AJ (2013) Carbon dioxide and climate impulse response functions for the computation of greenhouse gas metrics: a multi-model analysis. Atmos Chem Phys 13 (5):2793-2825. doi:10.5194/acp-13-2793-2013.

47. IPCC (2001) Climate Change 2001: The Scientific Basis. Contribution of Working Group I to the Third Assessment Report of the Intergovernmental Panel on Climate Change. IPCC Third Assessment Report - Climate Change 2001 Cambridge University Press, Cambridge, United Kingdom and New York, NY, USA.

48. Filbakk T, Høibø OA, Dibdiakova J \& Nurmi J (2011) Modelling moisture content and dry matter loss during storage of logging residues for energy. Scandinavian Journal of Forest Research 26 (3):267-277. doi:10.1080/02827581.2011.553199

49. Strömberg B \& Herstad Svärd S (2012) Bränslehandboken 2012 (The fuel handbook 2012). VÄRMEFORSK (Thermal Engineering Research Institute), Stockholm, Sweden.

50. Paulrud S, Fridell E, Stripple H \& Gustafsson T (2010) Uppdatering av klimatrelaterade emissionsfaktorer (Updated climate related emission factors). SMED 92 2010. Swedish Meteorological and Hydrological Institute (SMHI). Norrköping, Sweden.

51. Andersson G \& Frisk M (2013) Forestry transports in 2010. vol 791-2013. Skogforsk, Uppsala, Sweden.

52. Brunberg T (2013) Bränsleförbrukning hos skogsmaskiner 2012 (Fuel consumption in forest machines 2012). vol nr. 7892013. SKOGFORSK, Uppsala, Sweden.

53. Eliasson L \& Lundström H (2013) Skotning av hyggestorkad grot - Skotare med Hultdins Biokassett (Forwarding of dried logging residues - Study of Hultdins Biokassett). Skogforsk, Uppsala, Sweden.

54. Eliasson L, Granlund P, von Hofsten H \& Björheden R (2012) Studie av lastbilsmonterad kross-CBI 5800 (Study of truck-mounted CBI 5800 grinder). Skogforsk, Uppsala, Sweden.

55. Gode J, Martinsson F, Hagberg L, Öman A, Höglund J \& Palm D (2011) Miljöfaktaboken 2011. Uppskattade emissionsfaktorer för bränslen, el, värme och transporter (Environmental fact book 2011. Estimated emission factors for fuels, electricity, heat and transport (in Sweden with english abstract). vol ANLÄGGNINGS- OCH FÖRBRÄNNINGSTEKNIK 1183. Stockholm, Sweden.

56. Francescato V, Antonini E, Zuccoli Bergomi L \& et al. (2008) Wood Fuel Handbook. Italian Agriforestry Energy Association, Italy

57. Lehtikangas P (1999) Lagringshandbok för trädbränslen, 2:a upplaga (Storage handbbok for wood fuels, $2^{\text {nd }}$ edition). Swedish University of Agricultural Sciences (SLU). Uppsala, Sweden.

58. Uppenberg S, Almemark M, Brandel M, Lindfors L-G, Marcus H-O, Stripple H, Wachtmeister A \& Zetterberg L (2001) MILJÖFAKTABOK FÖR BRÄNSLEN (ENVIRONMENTAL FACT BOOK FOR FUELS). 2 edn., Stockholm, Sweden.

59. IPCC (2006) 2006 IPCC Guidelines for National Greenhouse Gas Inventories, Prepared by the National Greenhouse Gas Inventories Programme. IGES, Japan.

60. Swedish Forest Agency (2008) Rekommendationer vid uttag av avverkningsrester och askåterföring (Recommendations for extraction of logging residues and ash recycling) Skogsstyrelsens förlag, Jönköping, Sweden.

61. Emilsson S (2006) Handbok från skogsbränsleuttag till askåterföring. Swedish Forest Agency, Karlstad, Sweden.

62. Magnusson J \& Lindblad M (2013) Effektivare Askåterföring (Kombimetoden). Linnéuniversitetet, Växjö, Sweden

63. Hayhoe K, Kheshgi HS, Jain A \& Wuebbles DJ (2002) Substitution of Natural Gas for Coal: Climatic Effects of Utility Sector Emissions. Climatic Change 54 (1-2):107-139. doi:10.1023/A:1015737505552.

64. Uppenberg S, Almemark M, Brandel M, Lindfors L-G, Marcus H-O, Stripple H, Wachtmeister A \& Zetterberg L (2001) MILJÖFAKTABOK FÖR BRÄNSLEN Del 2. Bakgrundsinformation och Teknisk bilaga (ENVIRONMENTAL FACT BOOK FOR FUELS. Part 2. Background Information and Technical Appendix). B1334B. 2 edn., Stockholm, Sweden.

65. Cherubini F, Guest G \& Strømman AH (2013) Bioenergy from forestry and changes in atmospheric CO2: Reconciling single stand and landscape level approaches. Journal of Environmental Management 129 (0):292-301. doi:10.1016/j.jenvman.2013.07.021.

66. Lamers P \& Junginger M (2013) The 'debt' is in the detail: A synthesis of recent temporal forest carbon analyses on woody biomass for energy. Biofuels, Bioproducts and Biorefining 7 (4):373-385. doi:10.1002/bbb.1407. 